University of Nebraska - Lincoln

DigitalCommons@University of Nebraska - Lincoln

Field assessment of the risk posed by Diorhabda elongata, a biocontrol agent for control of saltcedar (Tamarix spp.), to a nontarget plant, Frankenia salina

\author{
Tom L. Dudley \\ University of Nevada \\ David J. Kazmer \\ USDA Agricultural Research Service
}

Follow this and additional works at: https://digitalcommons.unl.edu/usdaarsfacpub

Part of the Agricultural Science Commons

Dudley, Tom L. and Kazmer, David J., "Field assessment of the risk posed by Diorhabda elongata, a biocontrol agent for control of saltcedar (Tamarix spp.), to a nontarget plant, Frankenia salina" (2005). Publications from USDA-ARS / UNL Faculty. 355.

https://digitalcommons.unl.edu/usdaarsfacpub/355

This Article is brought to you for free and open access by the U.S. Department of Agriculture: Agricultural Research Service, Lincoln, Nebraska at DigitalCommons@University of Nebraska - Lincoln. It has been accepted for inclusion in Publications from USDA-ARS / UNL Faculty by an authorized administrator of DigitalCommons@University of Nebraska - Lincoln. 


\title{
Field assessment of the risk posed by Diorhabda elongata, a biocontrol agent for control of saltcedar (Tamarix spp.), to a nontarget plant, Frankenia salina
}

\author{
Tom L. Dudley ${ }^{\mathrm{a}, *, 1}$, David J. Kazmer ${ }^{\mathrm{b}}$ \\ a Department of Natural Resource and Environmental Science, MS 186, University of Nevada, Reno, NV 89512, USA \\ ${ }^{\mathrm{b}}$ USDA Agricultural Research Service, Northern Plains Agricultural Research Lab, P. O. Box 463 Sidney, MT 59270, USA
}

Received 27 August 2004; accepted 4 May 2005

Available online 7 July 2005

\begin{abstract}
The biological control program for saltcedar (Tamarix spp.) has led to open releases of a specialist beetle (Chrysomelidae: Diorhabda elongata) in several research locations, but the controversy over potential impacts to native, nontarget plants of the genus Frankenia remains unresolved. To assess the potential for nontarget impacts under field conditions, we installed cultivated Frankenia spp. (primarily two forms of Frankenia salina but also including Frankenia jamesii) at locations in Nevada and Wyoming where D. elongata densities and saltcedar defoliation were expected to be very high, so insects would be near starvation with high probability of attacking nontargets if these were suitable hosts. Subsequent insect abundance was high, and only minor impact $(<4 \%$ foliar damage) was observed on both forms of $F$. salina under these 'worst case' conditions; there was no impact to $F$. jamesii. No oviposition nor larval development were observed on any plants, there was no dieback of damaged $F$. salina stems, and plants continued growing once insect populations subsided. These results under 'natural' field conditions contrast with caged host-range tests in which feeding, development and minor oviposition occurred on the nontarget plant. Other ecological factors, such as distance from target plants to natural Frankenia spp. populations, inhospitable conditions for agent survival in such sites, and intrinsic insect behavior that makes colonization and/or genetic adaptation highly unlikely, lead us to conclude that nontarget impacts following program implementation will be insignificant or absent. Host range testing of new agents, while necessary to ensure safety, must put greater attention on assessing the ecological context where agents will be establishing, and on balancing speculated risks against potential benefits of biological control.
\end{abstract}

(C) 2005 Elsevier Inc. All rights reserved.

Keywords: Biological control; Host range testing; Nontarget impacts; Saltcedar; Tamarix; Diorhabda elongata; Frankenia

\section{Introduction}

Invasive plants are often difficult to control on a landscape scale using traditional chemical and mechanical methods, particularly in wildlands where collateral damage to other ecosystem elements can make effective con-

\footnotetext{
* Corresponding author. Fax: +1 8058938062 .

E-mail addresses: tdudley@msi.ucsb.edu (T.L. Dudley),dkazmer@ sidney.ars.usda.gov (D.J. Kazmer).

${ }^{1}$ Present address: Marine Science Institute, University of California, Santa Barbara, 93106-6150, USA.
}

trol impractical. To reduce the impacts of invasive plant control in natural settings, an alternate approach practiced over several decades is classical biological control of weeds (McFadyen, 1998; Newman et al., 1998). Identification of agents suitable for introduction entails a complex series of tests to ensure that their impacts will be both substantial and specific to the target weed. Extensive feeding trials are conducted overseas, and then in quarantine within the target country before an agent can be approved by USDA-APHIS for open release (Sheppard et al., 2003). 
Despite these precautions, there still exists some risk of unintended impacts because it is impossible to guarantee that any given ecological management prescription will be completely risk-free (Kluge, 1999; Louda et al., 2003; McEvoy, 1996). Increasing the ecological realism of the setting for evaluating agent performance should, in general, reduce the relative influence of experimental artifacts that might compromise results under highly controlled conditions. Although certainty regarding the risk of nontarget impacts may not be attained until the agent has been released and has established in the open field, we depend upon prerelease testing to determine the likelihood that such impacts will be acceptably low. Thus, it is useful to examine case histories to evaluate whether prerelease testing accurately predicts future nontarget impacts or whether these tests may, in fact, be unnecessarily conservative, resulting in rejection of effective candidate agents that pose little risk to natural ecosystems.

Saltcedar (Tamarix spp.; aka. tamarisk) is an invasive weed throughout the arid and semiarid western United States, and is considered to have negative economic and environmental impacts to water resources, channel integrity, and wildlife (Dudley et al., 2000; Shafroth et al., 2005; Zavaleta, 2000). It was targeted for biological control in the 1970s, and more than 300 specialist herbivores were identified on Tamarix spp. from Eurasia and northern Africa (DeLoach et al., 1996). Following a series of host range tests to ensure safety, in 1994 approval was given for release of two insects, a mealy bug [Pseudococcidae: Trabutina mannipara (Hemprich and Ehrenberg)] and a leaf-feeding beetle (Chrysomelidae: Diorhabda elongata Brullé) (DeLoach et al., 1996).

Host range testing involves exposure of nontarget plants, including economic and native species, to various forms of insect feeding and utilization. Those plants closely related to the target weed are considered foremost as potential nontarget hosts because their chemistry and other qualities may be similar to those of the target weed (Balciunas, 2000). In these original tests, native plants from the same suborder Tamaricineae (Frankeniaceae: Frankenia spp.) were used both alone and in combination with various Tamarix accessions to determine if significant damage would occur. Some feeding and development by $D$. elongata was observed with Frankenia, especially if no other food resource was available, but poor survival and the low levels of damage to nontarget plants relative to saltcedar was considered acceptable and the approval process went forward (U.S. Department of Agriculture-APHIS, 1999).

Heightened environmental sensitivity and a controversy over another form of potential nontarget impact (nesting by an endangered bird, the southwestern willow flycatcher [Empidonax traillii extimus (Phillips)] in saltcedar in some southwestern sites (Finch et al., 2002)) resulted in delays of the biocontrol program. In addition, concerns were renewed that Frankenia spp. may be put at risk by the introduction of agents to control Tamarix (DeLoach and Tracy, 1997). This issue necessitated additional nontarget host range studies before open releases of D. elongata could occur. Studies were conducted in quarantine facilities and other contained environments using several species of Frankenia native to North America, and again moderate feeding and oviposition were observed on Frankenia salina (Molina) I.M. Johnston (Lewis et al., 2003a). Although open release was allowed to proceed at several approved research sites in the western United States (DeLoach et al., 2004; Dudley et al., 2001), concern within federal agencies over potential impacts to Frankenia spp. continues to delay the implementation of this biological control program (DeLoach and Carruthers, 2003; DeLoach et al., 2003a,b, 2004). The study presented here is intended to document and evaluate the risk that $D$. elongata poses to native plants in 'natural' conditions, including when exposed to the most intense herbivory pressure that is likely to occur in the field.

\subsection{Experimental organisms and study sites}

The genus Frankenia is a widespread, morphologically diverse taxon with six representatives in North America (Lewis et al., 2003a; Whalen, 1987), and are the only plants in the same suborder as Tamarix on the North American continent. Many of the species are shrubs, and all are typically associated with saline or alkaline habitats. F. salina, or alkali heath, is a semiprostrate, rhizomatous perennial that grows in salt marsh habitats in the southwestern United States and northern Mexico, but does not occur in Nevada or Wyoming where these trials were conducted. Its distribution includes saltmarshes in coastal tidelands and interior alkali sinks (Munz, 1959); the coastal form was formerly known as $F$. grandifolia Cham. and Schlecht var. grandifolia and was synonymized with the inland form, F.g. var. campestris Grey (Whalen, 1987). Both varieties typically co-occur with Salicornia spp. and other halophytes requiring consistent moisture. A second species of Frankenia, Frankenia jamesii Torr. ex Gray, is a woody subshrub occurring on dry, saline sites from Colorado to Texas that has been tested in many of our laboratorybased host range studies, and was used in part of this study.

Diorahbda elongata is native to Eurasia and is oligophagous on the genus Tamarix (Lewis et al., 2003c). Both the larvae and adults feed externally on the foliage, which then desiccates beyond the feeding point to yield much greater impact than by consumption alone. The adults overwinter in the litter, and emerge in spring to commence feeding, and in northern regions two or more cohorts are produced during the season (Lewis et al., 2003b). The relationship with photoperiod determines 
both establishment success and number of generations at a given latitude (Bean, 2004), and reproductive biology is also complex (Cossè et al., 2005; Lewis et al., 2003b). The form present into both study sites is $D$. e. deserticola Chen from central Asia, and was released into the open field in spring 2001 (DeLoach et al., 2004; Dudley et al., 2001).

We tested the impact of $D$. elongata on Frankenia spp. at two sites among the 12 locations used for experimental development of Tamarix biocontrol, and where successful agent establishment had occurred the previous year. One is located $17 \mathrm{~km} \mathrm{SE}$ of Lovelock, Nevada, in the lower Humboldt River floodplain. The site was diked for water management, and is only periodically flooded by unusually high run-off (as occurred in 1983-1984, promoting the current saltcedar infestation; A. Brinkerhoff, landowner, personal communication). The substrate consists of fine alkaline silts representing deposition in the terminal lakebed of the Humboldt Sink. The form of saltcedar at this site is called Tamarix ramosissima for convenience, but apparently is a hybrid derived from $T$. ramosissima Deneb. and Tamarix chinensis Lour. that is common in the western United States (Gaskin and Schaal, 2002). It forms extensive stands in the region, and at the location where the trials were carried out, saltcedar provides approximately $45 \%$ aerial cover. This location was tilled prior to the 1983 flooding, and is generally lacking in native riparian flora except for the presence of saltgrass (Distichlis spicata (L.) Greene) and poverty-weed (Iva axillaris Pursh). Other common herbaceous species include perennial pepperweed/tall whitetop (Lepidium latifolium L.) and Russian knapweed (Acroptilon repens [L.] DC.), both of which are considered noxious weeds in the region.

The second test site is adjacent to Bighorn Lake on the Bighorn River, $18 \mathrm{~km}$ E. of Lovell, Wyoming. This reservoir is formed by Yellowtail Dam and, prior to dam completion in 1966, the test site was flood-irrigated cropland. The test site is above full pool level of Bighorn Lake and soil moisture at the site is elevated during the summer months by seepage from an irrigation canal. T. ramosissima, $T$. chinensis, and their hybrids dominate this site also. Other than saltcedar, the dominant plant species in the immediate vicinity of the test site are sandbar willow (Salix exigua Nutt.) and foxtail barley (Hordeum jubatum L.).

\section{Materials and methods}

For the Nevada trials, rhizomes of $F$. salina were collected from Owens Valley, California (inland) and from San Francisco Bay (coastal), and cultivated in a greenhouse during the winter of 2002-2003. Once rooted, individual plants were grown in 1-gallon plastic pots, and then transferred in spring to an outdoor planting table containing shallow water to acclimate to the outdoor climate. In addition, several bare-root $F$. jamesii were shipped to us from Colorado, planted into 2-gallon plastic pots in the greenhouse and later transferred outside but not held in water.

On 1 June 2003, the plants were transferred to the Lovelock experimental site, removed from their pots and planted into the native soil in association with existing, mature Tamarix plants. Adult D. elongata were in an explosive phase of colonization at this location. Two inland and one coastal $F$. salina were planted together ca. $30 \mathrm{~cm}$ apart in a shallow $(5 \mathrm{~cm}$ deep) depression formed to retain water. Four such groupings were installed, two in the open sunlight within $2 \mathrm{~m}$ south of the established Tamarix plants, and the other two in the shade underneath Tamarix such that insects could potentially drop directly onto the test plants. Two $F$. jamesii plants were installed in separate depressions in the open, and two in the shade. Thus, a total of eight inland and four coastal $F$. salina, along with four $F$. jamesii, were exposed to potential colonization by $D$. elongata. All plants initially received a commercial nitrate fertilizer $(2 \mathrm{~g})$ to assist in establishment, but none thereafter, and were watered through a plastic drip irrigation line controlled with a timer that delivered ca. $12 \mathrm{~L}$ of water every 2 days from a parked water truck.

Plants were observed approximately twice per month to count insects of all life stages, from date of planting until the experiment was terminated on 15 September (when water was cut off). Once plants had established ( 3 weeks after planting) and twice subsequently, the live lengths of 3 marked (with thread) major branches were measured and a count was made of the approximate number of leaves that had been fed upon. Branch length was measured from the branch base to the most terminal live, green tissue. At the time of termination, D. elongata was virtually absent from the study area (Table 1). Data on numbers of insects on plants, and feeding damage, were evaluated without analysis to characterize overall trends. Differences in impact between Frankenia varieties, and between shade vs. open treatments, were tested using two-way ANOVA where applicable. To assess 'risk' of attack on Frankenia in the field, we relied on counts of the average number of Diorhabda larvae and adults on two nearby Tamarix plants that were being monitored biweekly as part of the existing biocontrol program.

A control treatment (no exposure to herbivores) was not included because it was difficult to exclude larvae without altering plant growth conditions and the options for additional irrigated locations were limited. Furthermore, we were primarily concerned with determining whether plant utilization would occur, and less with comparing precise growth differences between treatments under these manipulated conditions. However, additional $F$. salina plants were also grown under outdoor conditions at the University of Nevada, Reno 
Table 1

Abundances of D. elongata on transplanted F. salina and on adjacent Tamarix at the Nevada site

\begin{tabular}{|c|c|c|c|c|c|c|}
\hline \multirow[t]{2}{*}{ Sampling date } & \multirow[t]{2}{*}{$\begin{array}{l}\text { Tamarix } \% \\
\text { live foliage }\end{array}$} & \multicolumn{2}{|c|}{$\begin{array}{l}\text { No. of D. elongata per } \\
\text { branch on Tamarix }\end{array}$} & \multicolumn{3}{|c|}{$\begin{array}{l}\text { Total number of } \\
\text { D. elongata on } F \text {. salina }\end{array}$} \\
\hline & & Adults & Larvae & Adults & Eggs & Larvae \\
\hline 9 June & 98 & 24 & 0 & 0 & 0 & 0 \\
\hline 21 June & 94 & 0.8 & 11 & 0 & 0 & 0 \\
\hline 1-5 July & 11 & 0 & 62 & 0 & 0 & 8 \\
\hline 15-18 July & 13 & 2.2 & 0 & 3 & 0 & 0 \\
\hline 2 August & 17 & 0 & 0.3 & 0 & 0 & 0 \\
\hline 12 August & 34 & 3.6 & 8.6 & 0 & 0 & 0 \\
\hline 5 September & 4 & 1.6 & 0.2 & 0 & 0 & 0 \\
\hline 15-25 September & 13 & 0 & 0 & 0 & 0 & 0 \\
\hline
\end{tabular}

Numbers on Tamarix represent means per monitored branch, four branches per plant, and \% live canopy is the mean estimate per tree; error estimates are not included because these two plants were not synchronized in colonization nor defoliation, and thus were highly variable, as the 'wave' of insects moved through the area. Insect numbers on $F$. salina are the totals for all plants combined. Larval and adult $D$. elongata numbers are experimental $F$. salina plants. Data were combined for all plants on each date due to very low numbers present during observations.

campus (140 km distant), where temperature and light conditions were similar to the experimental site so this provides some indication of growth potential in the absence of herbivores. The environmental conditions at the test site were not drastically different from those where $F$. salina naturally occurs, in moist alkaline clays or silts, so growth dynamics are probably similar to what is expected in sites such as Owens Valley, California.

An additional test was conducted to document whether D. elongata would oviposit on Frankenia when it was directly associated with Tamarix foliage where oviposition was occurring . On 14 July, when insect densities were very high and large numbers of both females and eggs were observed on Tamarix plants, two pots, each containing one healthy $F$. salina (inland), were placed directly into the canopy of a tree approximately $100 \mathrm{~m}$ away from the primary test area. One test pot fell from the tree after 3 days so was only observed during this initial period; the remaining plant was monitored periodically for 3 weeks and hand-watered weekly, after which it was retrieved and closely checked for eggs.

For the Wyoming site, $F$. salina from the inland (Owens Valley, CA) source were cultivated from 18 April to 15 July 2003 in plant growth chambers (16L:8D, $22.5^{\circ} \mathrm{C}$ ) at the Sidney, Montana laboratory. Bare-root plants were started in one-gallon pots filled with 'Sun- shine' soil mix (2:2:1 peat moss:vermiculite:perlite) in and continuously subirrigated. On 16 July 2003 , 25 potted plants were transported to the test site and buried to the pot brim underneath established saltcedar plants over an area of ca. $5000 \mathrm{~m}^{2}$. Sites were chosen where the soil was saturated with water from canal seepage. Plants were watered once on the day of pot burial, and thereafter high water content in the pot soil was maintained by existing subirrigation.

From 23 July to 3 September 2003, the test plants were monitored on five dates at weekly or greater intervals (see Table 2 for dates). The beginning of this sampling period coincided with the beginning of peak emergence of first-generation adult $D$. elongata at the Wyoming site. On each monitoring date, the numbers of eggs, larvae (by instar) and adult $D$. elongata on each live $F$. salina test plant were counted. Plants were also inspected for evidence of herbivory. On two of the monitoring dates and for each live $F$. salina plant, we measured the distance from the center of the pot to the nearest 3 D. elongata (egg cluster, larva, or adult) on saltcedar. Because this biocontrol agent is highly aggregated, we first calculated the mean distance to the nearest 3 D. elongata for each test plant and then calculated the mean and standard deviation of the distance across all test plants.

Table 2

Numbers of D. elongata observed on transplanted F. salina and distance from the F. salina plants to the nearest D. elongata on Tamarix at the Wyoming site on Tamarix (mean \pm SD [range])

\begin{tabular}{|c|c|c|c|c|c|c|c|}
\hline \multirow[t]{2}{*}{ Sampling date } & \multirow{2}{*}{$\begin{array}{l}\text { No. of } F \text {. salina } \\
\text { plants sampled }\end{array}$} & \multicolumn{5}{|c|}{ Total number of Diorhabda elongata on $F$. salina } & \multirow{2}{*}{$\begin{array}{l}\text { Distance }(\mathrm{m}) \text { to } \\
\text { nearest } D . \text { elongata }\end{array}$} \\
\hline & & Eggs & $\begin{array}{l}\text { 1st instar } \\
\text { larvae }\end{array}$ & $\begin{array}{l}\text { 2nd instar } \\
\text { larvae }\end{array}$ & $\begin{array}{l}\text { 3rd instar } \\
\text { larvae }\end{array}$ & Adults & \\
\hline 23 July & 25 & 0 & 0 & 0 & 0 & 1 & - \\
\hline 29 July & 25 & 0 & 0 & 0 & 0 & 0 & - \\
\hline 5 August & 25 & 0 & 0 & 0 & 0 & 0 & $1.03 \pm 0.30[0.35-2.03]$ \\
\hline 14 August & 25 & 0 & 0 & 1 & 1 & 0 & $1.05 \pm 0.33[0.40-1.95]$ \\
\hline 3 September & $24^{\mathrm{a}}$ & 0 & 0 & 0 & 0 & 0 & - \\
\hline
\end{tabular}

a One F. salina plant died between the August 13 and September 3 sampling dates. 


\section{Results}

\subsection{Nevada}

Overwintering $D$. elongata adults emerged in midMay of 2003, but did not become common on the Tamarix plants adjacent to the study site until the second generation matured in late June (Table 1). Numbers then generally declined until insects were nearly absent from the area at the time of experiment termination in mid-September. However, this is an inadequate indicator of the potential impact that these herbivores may have posed to the nontarget Frankenia spp. At the time of peak insect abundance, saltcedars were almost completely defoliated (Table 1; maximum foliar loss on individual index plants was $>98 \%$ ) and larvae were leaving the plants in large numbers in late June and early July in search of alternative forage. Within the vicinity of the Frankenia test plants larval densities greater than 5000 individuals $/ \mathrm{m}^{2}$ were observed (based on counts in 10 , $10 \times 10 \mathrm{~cm}$ quadrats, mean density 34 larvae per quadrat with some quadrats containing $>50$ larvae). All surrounding saltcedar trees were equally defoliated, such that the only available forage was the Frankenia plantings and various weedy or herbaceous plants (including $D$. spicata, Iva axillaris, L. latifolium, and $A$. repens).

Both larvae and adults of $D$. elongata were found in very small numbers on $F$. salina, even at the time of greatest larval dispersal from defoliated Tamarix (Table 1). There were no perceivable differences in counts between the two types (inland vs. coastal), nor related to location (sun vs. shade), owing to small numbers of insects found on the plants. No eggs were ever found on any plant in this experiment.

There was observable feeding by insects on $F$. salina (Fig. 1), with an average of $32 \%$ of leaves showing any damage (Fig. 2). This was confined to 'nibbling' on leaf margins at the distal portions of stems giving a slightly 'ragged' look to the plants and never appeared to involve more than about $5-10 \%$ tissue loss from any single leaf (thus, a maximum of roughly $2-4 \%$ of total leaf area may have been consumed). There was no statistical difference in impact between the two $F$. salina varieties nor between light environments, although small sample sizes make it difficult to distinguish differences (Fig. 2; $F_{\text {location }}=1.81, p>0.21 ; F_{\text {variety }}=1.72, p>0.22 ; F_{\text {interaction }}$ $=0.25, p>0.6, d f=1$ for each factor). A trend toward greater feeding on the coastal variety of $F$. salina may have been because these plants were ca. $10 \%$ smaller in size and if feeding is concentrated toward the branch tips then these provide a greater proportion of available foliar tissue. Likewise, the tendency toward more damage in the open was possibly because these plants were also somewhat smaller than the matched shade plants, but also dispersing larvae were presumably moving away from the defoliated saltcedar plants that created the 'shade' treatment so they are more likely to encounter Frankenia in the open.

Most of the damage was caused by D. elongata larvae, as the rare adults on test plants were not observed to be feeding and dropped off readily when slightly disturbed, unlike larvae that were more tightly attached. The semisucculent Frankenia may also be attractive to other widespread herbivores, such as flea beetles, grasshoppers, harvester ants and thrips, and even armyworms, cutworms, loopers (Noctuidae and Geometridae), and alfalfa weevils from nearby host plants. Damage from these 'generalists' could be similar to that observed; however, other insects were infrequently observed and their effects were probably relatively minor. After midAugust no further $D$. elongata activity was seen on F. salina, and despite substantial regrowth of foliage on nearby Tamarix, there was very little recolonization of the area by the beetles (Table 1).

All $F$. salina plants remained healthy in appearance until the study was terminated, and did not decrease in live branch length despite some feeding damage (Fig. 3). Unlike Tamarix, in which even minor feeding damage leads to desiccation and major foliage losses, damaged leaves of $F$. salina did not experience subsequent decline. Plant growth may have been slowed during the period of high insect abundance, but resumed again once the insect population had declined locally (Fig. 3). Neither plant variety nor light conditions had any influence on branch length at the mid-season date when feeding occurred $\left(F_{\text {variety }}=0.05, p>0.8 ; F_{\text {location }}=0.66, p>0.44\right.$; $F_{\text {interaction }}=0.16, p>0.7, d f=1$ for each factor), although the low replication limited the ability to detect subtle differences. Final proportionate growth in branch length did not differ with respect to plant origin, but plants in the shade grew substantially more (Fig. $3 ; F_{\text {variety }}=0.02$, $p>0.9 ; \quad F_{\text {location }}=12.41, \quad p<0.01 ; \quad F_{\text {interaction }}=2.70$, $p>0.14, d f=1$ for each factor). Shaded plants were presumably under less physiological stress than those in the direct desert sun, or in the shade there may have been a tendency toward etiolated stem growth. It is unlikely that prior herbivory was related to open vs. shade differences, given the small extent of impact and the absence of visible damage later in the experiment. Plants that were held outdoors at our Reno facility, although not intended as controls for the field trials, did continue to grow during the same period and under less stressful growth conditions were only marginally larger (approx. $21 \mathrm{~cm}$ branch length vs. $13-18 \mathrm{~cm}$ for field plants).

Oddly enough for a marsh-restricted plant, at least five plants (four inland and one coastal) survived the winter and grew new leaves in the following spring, despite no augmented water. These initially appeared healthy and were unaffected when D. elongata became active in 2004, but finally succumbed in the arid environment.

The $F$. salina plants placed within the Tamarix canopy were not attacked, although casual observations on 


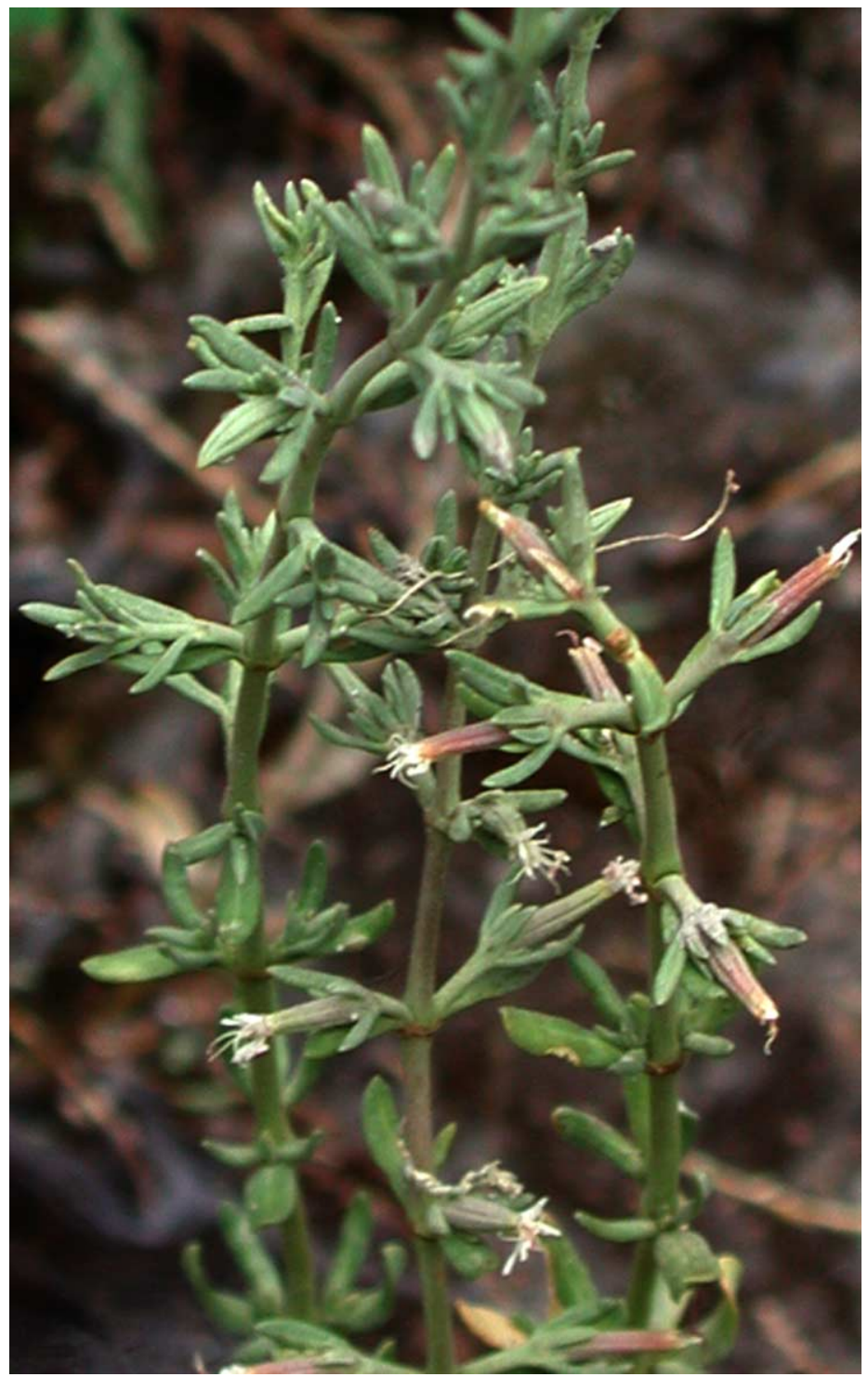

Fig. 1. Photograph of a F. salina test plant showing type of leaf surface damage caused by $D$. elongata, and illustrating general plant appearance. For scale, mature leaves are approximately 0.7 to $1.0 \mathrm{~cm}$ in length.

two occasions indicated that some adults did alight on the plants. No damage was observed, and no eggs nor larvae were present on the fallen plant (3 days exposure) or the surviving plant when it was retrieved after 3 weeks and examined with a hand lens.

Frankenia jamesii never showed any evidence of feeding damage, nor were any insects or eggs ever found on these plants. Although plants were alive at the end of the experiment, roughly half of each appeared healthy and was producing new tissue, while other portions showed dieback, presumably because this species is not adapted to the wet conditions created by the irrigation treatment.

\subsection{Wyoming}

The D. elongata population at this site achieved roughly equivalent high densities as at the Nevada site, and moderate to extensive defoliation was observed on all saltcedar in association with the $F$. salina test plants. Over the five sampling dates (124 live test plant inspections), a total of three $D$. elongata individuals were observed; two larvae on one plant and one adult on another (Table 2). The mean distances to the nearest D. elongata on saltcedar from the test plants were 1.03 and $1.04 \mathrm{~m}$ on 5 August and 14 August, respectively, and the greatest measurement recorded was $2.03 \mathrm{~m}$ (Table 2). These distances indicated that $D$. elongata was generally present on the saltcedar foliage immediately above the buried test plants. Most of nearest D. elongata on saltcedar were larvae $(93.3 \%$ and $96.0 \%$ on 5 August and 14 August, respectively).

No evidence of herbivory by $D$. elongata was observed on any $F$. salina plant. One of the test plants died between 14 August and 3 September, and five of six 


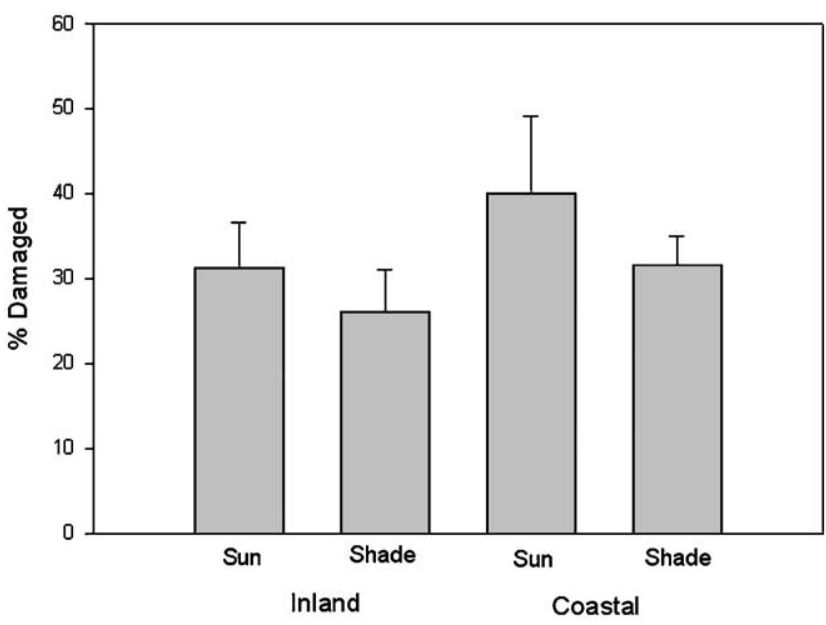

Fig. 2. Proportion of total $F$. salina leaves ( $\pm 1 \mathrm{SE}$ ) showing any damage by herbivory on 19 July (ANOVA summary in text).

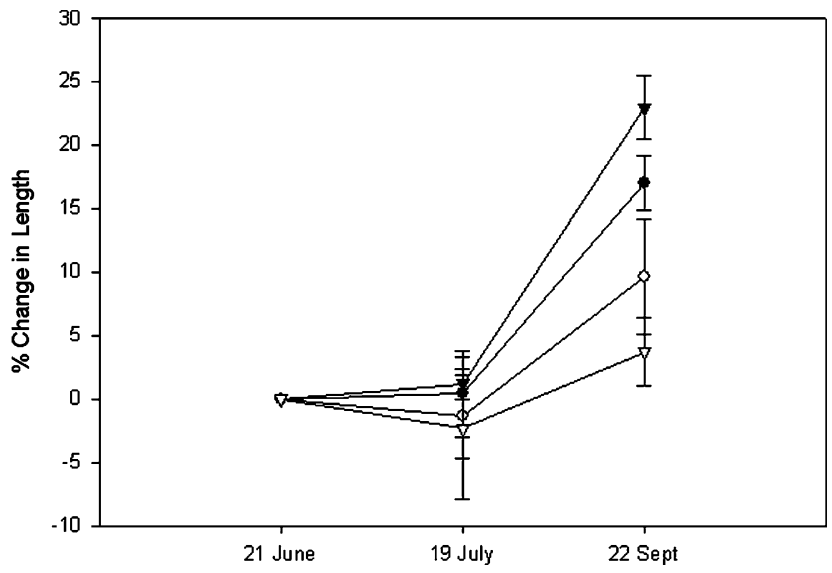

Fig. 3. Change in mean branch lengths ( $\pm 1 \mathrm{SE})$ for $F$. salina test plants between sampling dates (ANOVA summary in text). Initial branch length means on 21 June were similar $(13-15 \mathrm{~cm})$ for all treatments. Triangles represent coastal plants and circles indicate inland plants; open symbols are plants in the open sun and closed symbols indicate plants grown under Tamarix shade.

basal branches on one other plant were dead at the end of the study. Leaves on the dead branches of these two plants were complete and intact; the cause of branch death was not known.

\section{Discussion}

The introduction of non-native organisms into the United States to control environmental weeds has become controversial, in large part owing to concern that introduced agents may have unintended impacts to nontarget hosts and/or indirect effects on natural communities (Louda and Stiling, 2004; McEvoy, 1996; Marohasy, 1996; van Klinken and Edwards, 2002). Thus, caution is important not only to reduce the potential for such impacts, but also to enhance the confidence of resource agencies and the public that risk is being minimized (Sheppard et al., 2003).

In conducting host range tests of candidate biological control agents there is always some degree of uncertainty when extending results of experimental feeding and oviposition tests to predictions of impacts under field conditions. The artificial conditions imposed by cages in quarantine facilities are bound to alter feeding and oviposition behavior of insects to some extent, as was indicated in previous Frankenia studies (DeLoach et al., 2003b; Lewis et al., 2003a). The greater the degree of simulation of natural conditions, the greater the probability that responses may reflect true impacts in the natural system. Thus, the exposure of a nontarget native plant grown under field conditions where the agent has established, as is the case with the open release of D. elongata at the two sites in this study, is an important logical step in validating the ecological 'safety' of a biocontrol agent before its widespread dissemination (Louda et al., 2003). This particular agent is intended for release soon in at least 14 states (Richard, 2003), so the experiments described here are highly relevant, particularly given the pressure both for and against its introduction throughout the western USA (Dudley and DeLoach, 2005).

In our experiments in two of the states (Nevada and Wyoming) where experimental open releases have been conducted, we found that $D$. e. deserticola (the subspecies released in both cases) either did not feed (Wyoming) on a nontarget host, $F$. salina, or that feeding damage was trivial (Nevada). Incidental herbivory caused less than $4 \%$ damage to the test plant foliage at the Nevada site, from which the plants rapidly recovered and showed no apparent sustained effects. Some utilization was expected, based on numerous quarantine and cage studies (DeLoach et al., 2003b, 1996; Lewis et al., 2003a), but in many previous tests, all of which were in laboratory conditions, both oviposition and larval development also occurred on the nontarget Frankenia spp. (Lewis et al., 2003a; J. Herr, USDA-ARS, Albany, California, unpublished data). No oviposition, however, was observed on any plant in this study. Very low numbers of insects were sporadically present on some test plants and there was no evidence that larvae developed to maturity. A congener from the midcontinental United States, $F$. jamesii, received no impact from this herbivore under open field conditions.

Sometimes an atypical plant host will be fed upon when the herbivore is forced to subsist solely on this resource, but it is important to consider whether this represents 'normal' behavior or is an artifact of the experimental conditions. In previous host range tests, $D$. elongata adults oviposited on $F$. salina plants, but at frequencies much lower than on the target host $(<10 \%$ of oviposition in choice tests and usually $0.0 \%$ ), and often more eggs were deposited on cage walls than on nontar- 
get plants (DeLoach et al., 2003b; Lewis et al., 2003a; J. Herr, unpublished data). In those trials, the larger the cage and the more ecologically realistic the growth conditions, the less was the utilization of these nontarget hosts. In a related trial in 2002, six F. salina plants grown in pots were placed into tubs inside a large $(2.5 \times 2.5 \times 6 \mathrm{~m})$ experimental cage containing both $T$. ramosissima and D. elongata at our Owens Valley, California study site. Insect densities and target defoliation were similarly high, yet no damage was observed and no eggs were found on Frankenia, despite their placement directly below defoliated plants (T. Dudley, unpublished data). Our collaborator in Colorado (D. Eberts, U.S. Bureau of Reclamation) conducted a similar trial using $F$. jamesii with resulting absence of impact (DeLoach et al., 2003b).

The experiments reported here represented a 'worst case scenario,' in which herbivore densities were extraordinarily high, the nontarget plants were in almost direct contact with the target host plants, and insects were starving and dispersing from defoliated target plants, particularly at the Nevada test site. Such conditions are not expected under normal circumstances, and in fact, the Wyoming results with no observed impact are probably more typical of initially high biocontrol agent populations. Equally important, the minor impact that did occur at the Nevada site was readily compensated by plant growth, with no mortality or stem dieback. Perennial, deciduous plants like $F$. salina can recover readily from short-term damage to maintain high vegetative cover in their natural habitats, and only infrequently rely on sexual reproduction to maintain populations (Crawley, 1989). In its natural habitat $F$. salina experiences regular herbivory from much more abundant herbivores (Maffei, 2000) with little apparent impact on its distribution pattern. Thus, the population consequences of incidental Frankenia herbivory are insignificant, which is key to assessing nontarget impacts (Louda et al., 2003).

The capacity to feed to a limited extent on a nontarget plant under experimental conditions does not directly infer that such impacts are ecologically realistic, and evaluation of the potential for nontarget effects of biocontrol should take ecological context into account. Our experimental trials required transplanting of nontarget plants from their natural habitat, which in the case of $F$. salina is saturated salt marsh, into locations where they do not naturally occur and cannot survive. There are few locations where these taxa (Tamarix spp. and $F$. salina) occur in close proximity. One is in the Owens Valley, California, and two coastal sites are known, both near the California/Mexico border. These sites involve low densities of saltcedar adjacent to, but not overlapping with, $F$. salina, which forms an extensive, prostrate mat generally interspersed with Salicornia sp. Beetle larvae could theoretically move from Tamarix to Frankenia in these situations, but this is unlikely because sparse or isolated saltcedar plants would rarely produce large numbers of dispersing larvae. Larvae are typically killed by drowning when they contact water, as would be expected at such sites. Also, D. elongata must both pupate and overwinter at the soil-litter interface (Lewis et al., 2003b), so cannot survive these wet and anoxic conditions and almost certainly could not establish populations in Frankenia habitat.

Other ecological factors further reduce the risk of nontarget effects. Populations of $F$. salina further removed from Tamarix cannot be reached by D. elongata larvae, which are also very susceptible to predation (Herrera et al., 2001). Remote plants are highly unlikely to be 'discovered' by dispersing adults because adults aggregate on host plants in response to both plant volatile compounds and male pheromones (Cossè et al., 2005). Other Frankenia species occur in the general areas of some Tamarix infestations, but again these are rarely locally sympatric and are even less suitable as hosts that is $F$. salina (Lewis et al., 2003a).

Because the impacts to Frankenia were transitory but real, what is the possibility that a novel host-herbivore interaction can become established, in which case the future potential for more substantial impact may be a concern? Evolution of new host associations, or hostswitching, is known to occur but typically involves closely related taxa (Craig et al., 2000; Louda et al., 2003; Sheldon and Jones, 2001; but see Hight et al., 2004) and would be expected to require multiple generations (tens to hundreds) of association with the new host (Thompson, 1998). Assuming that Frankenia spp., and F. salina in particular, are suitable for larval and adult development, the ecological arguments raised above strongly infer that there is insufficient opportunity for the genetic isolation (via spatial, temporal, or behavioral mechanisms) necessary for rapid evolution of novel host specificity (cf., Marohasy, 1996; van Klinken and Edwards, 2002). These authors explain that most cases labeled as host-switching instead involve novel use of plants within the existing host range, but caution that quantitative genetic changes in their utilization is not impossible, even inferior ones such as Frankenia spp. Aggregation or swarming behavior of adult D. elongata, as occurs on larger plants where the host plant chemical cue promotes aggregation (Cossè et al., 2005), would make reproductive isolation essentially impossible. Beetles cultured on $F$. salina vs. T. parviflora showed no difference in host preference (Lewis et al., 2003a), further suggesting that local or host-specific adaptation, and increased use of Frankenia spp. in nature, would not be expected. Again, we do not see a rational mechanism for evolution of such novel host utilization, and lack of associations between D. elongata and Frankenia spp. in Eurasia (Kovalev, 1995) suggests that such evolution would not be expected in the new geographic ranges of both the biocontrol agent and its target weeds. 
Other Diorhabda genotypes that also specialize on Tamarix spp. are being released, or proposed for release, in some sites where their development may be better synchronized with the environment (Bean, 2004; DeLoach et al., 2004). In prerelease host range testing there may have been a trend toward greater development and oviposition on $F$. salina by at least one other genotype from the Mediterranean region, but little significant difference in utilization among genotypes (DeLoach and Carruthers, 2003; DeLoach et al., 2004). New genotypes of the biocontrol agent should receive some level of nontarget host testing, but if results are generally similar to those in previous trials (and recognizing the artifacts imposed by cage testing), exhaustive new testing is unnecessary, especially when the ecological context remains inappropriate for population establishment on Frankenia spp. in nature.

There is presumably general agreement that standard mechanical and chemical weed control methods have unintended, negative effects on ecosystems and many nontarget organisms, and also that the 'do nothing' alternative of allowing weed invasions to increase is unacceptable. There is less agreement, or even discussion, about the level of risk to native plants that is acceptable, and potentially outweighed by the benefits of controlling invasive plants (Carruthers, 2004; Frank, 1998; Kluge, 1999; Louda and Stiling, 2004). While we concur with critics of biological control that it is important to minimize the risks of biocontrol agents to economic and environmental resources, we are concerned that excessive caution may be applied in some cases, bordering on a zero-risk approach regarding potential impacts of those agents in natural areas (Louda and Stiling, 2004; Randall and Tu, 2003).

Excessive caution can be counter-productive (and costly) when it inhibits environmentally beneficial control programs (Dudley and DeLoach, 2005). This mindset also contributes to an alarmist perception of biocontrol in society while forcing public agencies and researchers to become unduly conservative in the testing and approval of biocontrol agents (Kluge, 1999). Agents that have shown promise against weeds are routinely rejected when it is determined from laboratory studies that they can feed on other nontarget hosts, despite doubts that the threats would be realized under field conditions (e.g., McFadyen and Weggler-Beaton, 2000). In at least one case, however, an agent that caused nontarget impacts in host range testing was considered inappropriate for release, yet when unintentionally released, it did not exhibit substantive use of the nontarget plant (Balciunas and Villegas, 2001). We would caution that results from highly abstracted experimental studies cannot easily be extrapolated to field conditions without thoughtful consideration of the ecological context where releases would take place to determine if nontarget risks are realistic. In the case of risks posed by Diorhabda introductions to native Frankenia spp., it is increasingly clear that the hypothesized impacts are minimal or nonexistent, and should no longer hinder the progress of the Tamarix biocontrol program. Further testing may be academically interesting, but will not, we believe, substantially contribute to the protection of biodiversity and restoration of functional riparian ecosystems.

\section{Acknowledgments}

We appreciate the efforts of individual members of the Saltcedar Biological Control Consortium for their contributions to this collaborative program. We especially acknowledge Dave LaClergue, Annie Caires, John Herr, and Debra Eberts for assistance in the field, supplying test plants, or providing unpublished data related to this study. We thank Carla D'Antonio and two anonymous reviewers for their useful comments on the manuscript. Financial support is, in part, from USDA-IFAFS Grant No. 00-52103-9647.

\section{References}

Balciunas, J., 2000. Code of best practices for classical biological control of weeds, In: Spencer, N.R. (Ed.), Proceedings of the X International Symposium on Biological Control of Weeds. Montana State University, Bozeman, p. 435.

Balciunas, J.K., Villegas, B., 2001. Unintentionally released Chaetorellia succinea (Diptera: Tephritidae): is this natural enemy of yellow starthistle a threat to safflower growers? Envir. Entomol. 30, $953-$ 963.

Bean, D.W., 2004. Matching diapause and overwintering properties with release sites of Diorhabda elongata. Symposium: The biological control of saltcedar (Tamarix spp.): multidisciplinary approaches enhance success. Entomol. Soc. America, Salt Lake City, Utah, 17 Nov. 2004. http://esa.confex.com/esa/2004/techprogram/ session_1929.htm.

Carruthers, R.I., 2004. Biological control of invasive species, a personal perspective. Conserv. Biol. 18, 54-57.

Cossè, A.A., Bartelt, R.J., Zilkowski, B.W., Bean, D.W., Petroski, R.J., 2005. Identification of the aggregation pheromone of Diorhabda elongata (Coleoptera: Chrysomelidae) a biological control agent of saltcedar (Tamarix spp.). J. Chem. Ecol. 31, 657-670.

Craig, T.P., Itami, J.K., Shantz, C., Abrahamson, W.G., Horner, J.D., Craig, J.V., 2000. The influence of host plant variation and intraspecific competition on oviposition preference and offspring performance in the host races of Eurosta solidaginis. Ecol. Entomol. 25, 7-18.

Crawley, M.J., 1989. The relative importance of vertebrate and invertebrate herbivores in plant population dynamics. In: Bernays, E.A. (Ed.), Insect-Plant interactions. CRC Press, Boca Raton, FL, pp. $41-57$.

DeLoach, C.J., Carruthers, R.I., 2003. Test Results of the Leaf Beetle, Diorhabda elongata, from Crete for Biological Control of Saltcedar and Request to APHIS for Permits to Release in Field Cages and in the Open Field. Report to USDA-ARS, Temple, Texas, May 2003.

DeLoach, C.J., Carruthers, R.I, Dudley, T.L., 2003a. Request to U.S. Fish \& Wildlife Service for Additional New Sites for Release of the Leaf Beetles, Diorhabda elongata from Eurasia, for Biological Control of Saltcedar (Tamarix spp.) in Seven Western States. USDAARS, Temple, Texas, February 2003. 
DeLoach, C.J., Carruthers, R.I., Dudley, T.L., Nibling, F., Thompson, D., 2003b. Update on Request to U.S. Fish and Wildlife Service for Additional New Sites for Release of the Leaf Beetles, Diorhabda elongata from Eurasia, for Biological Control of Saltcedar (Tamarix Spp.) in the Western U.S. with Update on Research during 2002-2003. USDA-ARS, Temple, Texas, December 2003.

DeLoach, C.J., Carruthers, R., Dudley, T., Eberts, D., Kazmer, D., Knutson, A., Bean, D., Knight, J. Lewis, P., Tracy, J., Herr, J., Abbot, G., Prestwich, S., Adams, G., Mityaev, I., Jashenko, R., Li, B., Sobhian, R., Kirk, A., Robbins, T., Delfosse, E., 2004. First results for control of saltcedar (Tamarix spp.) in the open field in the western United States. In: Cullen, W., Briese, D.T., Kriticos, D.J., Lonsdale, W.M., Morin, L., Scott, J.K. (Eds.), Proceedings of the XI International Symposium on Biological Control of Weeds, CSIRO Entomology, Canberra, Australia, pp. 505-513.

DeLoach, C.J., Gerling, D., Fornasari, L., Sobhian, R., Myartseva, S., Mityaev, I.D., Lu, Q.G., Tracy, J.L., Wang, R., Wang, J.F., Kirk, A., Pemberton, R.W., Chikatunov, V., Jashenko, R.V., Johnson, J.E., Zeng, H., Jiang, S.L., Liu, M.T., Liu, A.P., Cisneroz, J., 1996. Biological control programme against saltcedar (Tamarix spp.) in the USA: progress and problems. In: Moran, V.C., Hoffmann, J.H. (Eds.) Proceedings of the IX International Symposium on Biological Control of Weeds. University of Capetown, South Africa, pp. 253-260.

DeLoach, C.J., Tracy, J.L., 1997. Effects of Biological Control of Saltcedar (Tamarix ramosissima) on Endangered Species, Draft Biological Assessment, USDA-ARS, Temple, Texas.

Dudley, T.L., DeLoach, C.J., Lewis, P.A., Carruthers, R.I., 2001. Cage tests and field studies indicate leaf-eating beetle may control saltcedar. Ecol. Restoration 19, 260-261.

Dudley, T.L., DeLoach, C.J., Lovich, J., Carruthers, R.I., 2000. Saltcedar invasion of western riparian areas: impacts and new prospects for control. Trans. No. Amer. Wildlife and Nat. Res. Conf., Chicago, 65, 345-381.

Dudley, T.L., DeLoach, C.J., 2005. Saltcedar (Tamarix spp.), endangered species and biological weed control — can they mix? Weed Technol. 18, 1542-1551.

Finch, D.M., Rothstein, S.I., Boren, J.C., Graf, W.L., Holechek, J.L., Marshall, R.M., Pohl, M.M., Sferra, S.J., Stromberg, J.C., Valentine, B.A., Whitfield, M.J., Williams, S.O., 2002. Final Recovery Plan: Southwestern Willow Flycatcher (Empidonax traillii extimus). Region 2, U.S. Fish and Wildlife Service, Albuquerque

Frank, J.H., 1998. How risky is biological control?: Comment. Ecology 79, 1829-1834.

Gaskin, J.F., Schaal, B.A., 2002. Hybrid Tamarix widespread in US invasion and undetected in native Asian range. Proc. Natl. Acad. Sci. USA 99, 11256-11259.

Herrera, A.M., Carruthers, R.I., Dahlsten, D., Dudley, T., 2001. Field studies of Diorhabda elongata (Coleoptera: Chrysomelidae) larval survivorship, a biological control agent introduced against saltcedar (Tamarix ramosissima) in the western U.S. (abstract). Annual Meeting, Ent. Soc. of America, San Diego. http://esa.confex.com/ esa/2001/techprogram/paper_3491.htm.

Hight, S., Pemberton, R., Conant, P., Johnson, T., 2004. Attack on and use of a native Hawaiian plant by a biological control agent (Teleonemia scrupulosa) introduced against Lantana camara. In: Cullen, W., Briese, D.T., Kriticos, D.J., Lonsdale, W.M., Morin, L., Scott, J.K. (Eds.), Proceedings of the XI International Symposium on Biological Control of Weeds, CSIRO Entomology, Canberra, Australia, p. 350.

Kluge, R.L., 1999. The future of biological control with insects: no more 'paranoia', no more 'honeymoon'. In: Spencer, N.R. (Ed.) Proceedings of the X International Symposium on Biological Control of Weeds. Montana State University, Bozeman, pp. 459-467.

Kovalev, O.V., 1995. Co-evolution of the tamarisks (Tamaricaceae) and pest arthropods (Insecta; Arachnida: Acarina), with special reference to biological control prospects. Russ. Acad. Sci., Proc. Zool. Inst. 259. Pensoft Publ., Sofia, Bulgaria.
Lewis, P.A., Herr, J.C., Dudley, T.L., Carruthers, R.I., DeLoach, C.J., 2003a. Assessment of risk to native Frankenia shrubs from an Asian leaf beetle, Diorhabda elongata deserticola (Coleoptera: Chrysomelidae), introduced for biological control of saltcedars (Tamarix spp.) in the western United States. Biol. Control 27, 148166.

Lewis, P.A., DeLoach, C.J., Knutson, A.E., Tracy, J.L., Robbins, T.O., 2003b. Biology of Diorhabda elongata deserticola (Coleoptera: Chrysomelidae), an Asian leaf beetle for biological control of saltcedars. (Tamarix spp.) in the US. Biol. Control 27, 101-116.

Lewis, P.A., DeLoach, C.J., Herr, J.C., Carruthers, R.I., Tracy, J.L., Johnson, J., 2003c. Host specificity of a leaf beetle, Diorhabda elongata deserticola (Coleoptera: Chrysomelidae) from Asia, for biological control of saltcedars (Tamarix: Tamaricaceae) in the western United States. Biol. Control 27, 117-147.

Louda, S.M., Stiling, P., 2004. The double-edged sword of biological control in conservation and restoration. Conserv. Biology 18, $50-53$.

Louda, S.M., Pemberton, R.W., Johnson, M.T., Follett, P.A., 2003. Nontarget effects-the Achilles' heel of biological control? Retrospective analyses to reduce risk associated with biocontrol introductions. Annu. Rev. Entomol. 48, 365-396.

Maffei, W., 2000. A note on the invertebrate populations of the San Francisco Estuary. In: Olofson, P.R. (Ed.), Goals Project: Baylands Ecosystem Species and Community Profiles. San Francisco Bay Regional Water Quality Control Board, Oakland, CA, pp. 184-192.

McEvoy, P.B., 1996. Host specificity and biological pest control. BioScience 46, 401-405.

McFadyen, R.E., Weggler-Beaton, K., 2000. The biology and host specificity of Liothrips sp (Thysanoptera: Phlaeothripidae), an agent rejected for biocontrol of annual ragweed. Biol. Control 19, 105-111.

McFadyen, R.E.C., 1998. Biological control of weeds. Annu. Rev. Entomol. 43, 369-393.

Marohasy, J.J., 1996. Host shifts in biological control: real problems, semantic difficulties or poor science? Internat. J. Pest Manage. 42, 71-75.

Munz, P.A., 1959. A California Flora. University of California Press, Berkeley.

Newman, R.M., Thompson, D.C., Richman, D.B., 1998. Conservation strategies for the biological control of weeds. In: Barbosa, P. (Ed.), Conservation biological control. Academic Press, New York, pp. 371-396.

Randall, J.M., Tu, M., 2003. Weed Control Methods Handbook: Tools and Techniques for Use in Natural Areas: Biological Control. http://tncweeds.ucdavis.edu/handbook.html.

Richard, R., 2003. Proposed Program for Control of Saltcedar (Tamarix spp.) in Fourteen States: Draft Environmental Assessment. USDA-APHIS, Ft. Collins, CO. November 2003.

Shafroth, P.B., Cleverly, J., Dudley, T.L., Stuart, J., Van Riper, C., Weeks, E.P., 2005. Saltcedar removal, water salvage and wildlife habitat restoration along rivers in the southwestern U.S.. Envir. Manage. 35, 231-246.

Sheldon, S.P., Jones, K.N., 2001. Restricted gene flow according to host plant in an herbivore feeding on native and exotic watermilfoils (Myriophyllum: Haloragaceae). Internat. J. Plant Sci. 162, 793-799.

Sheppard, A.W., Hill, R., DeClerk-Floate, R.A., McClay, A., Olckers, T., Quimby, P.C., Zimmermann, H.G., 2003. A global review of risk-benefit-cost analysis for the introduction of classical biological control agents against weeds: a crisis in the making? Biocontrol News Inf. 24, 77N-94N.

Thompson, J.N., 1998. The evolution of diet breadth: monophagy and polyphagy in swallowtail butterflies. J. Evol. Biol. 11, 563-578.

U.S. Department of Agriculture-APHIS. 1999. Field Release of a Nonindigenous Leaf Beetle, Diorhabda elongata (Coleoptera: Chrysomelidae) for the Biological Control of Deciduous Saltcedar, Tamarix ramosissima and T. parviflora (Tamaricaceae). Environ- 
mental Assessment. http://www.aphis.usda.gov/ppd/es/ppqdocs html.

van Klinken, R.D., Edwards, O.R., 2002. Is host-specificity of weed biological control agents likely to evolve following establishment?. Ecol. Lett. 5, 590-596.
Whalen, M.A., 1987. A Systematic Review of the New World Species of Frankenia (Frankeniaceae). Ph.D. dissertation, University of Texas, Austin.

Zavaleta, E., 2000. The economic value of controlling an invasive shrub. Ambio 29, 462-467. 